\title{
Search for Spanish Civil War Victims in the Cemetery of Sant Ferran, Formentera (Spain): Oral Witness Testimonies, Secondary Deposition Site, and Perimortem Trauma
}

\author{
Almudena García-Rubio, Juanjo Marí Casanova, \\ Glenda Graziani, Francisca Cardona, Pau Sureda, \\ Sergi Moreno, and Nicholas Márquez-Grant
}

\section{CONTENTS}

Introduction

The Cemetery of Sant Ferran in Formentera

Archaeological and Anthropological Investigation 3

The Ossuary

Identifying of the Deceased and Reconstruction of the Events

Lessons Learned

Discussion Questions

Acknowledgments

Notes

References

\section{INTRODUCTION}

The Spanish Civil War (1936-1939) resulted in a high number of civilians killed as a result of the conflict between the Fascist or Nationalist Regime of Francisco Franco and the Republican faction. Thousands of civilians were killed as a result of violence behind the frontline. The figures of those killed during the Civil War and the first ten years of the dictatorship that followed have been estimated at 49,272 from the Republican Repression and 130,179 from the Francois repression (Preston, 2012). Excluding those killed by bombings in a number of towns and cities, as well as those who died during exile or through battle, there were those summarily executed during paseos ("walks") where they 
were walked out to fields or forests, during sacas (mass killings of prisoners) and those killed near cemeteries (Juliá, 1999).

After the Spanish Civil War, a number of exhumations were carried out by those of the victorious side (Francoist regime). These exhumations are a result of the Government ordinances of 1939 and 1940 that stated that those who wanted to exhume the remains of their relative killed by the Marxists (Republicans) to later inter them in a cemetery can do so within six months of the publication of those ordinances and at no cost (BOE 130:3207). Between the death of Francisco Franco in 1975 and the coup d'état of 1981, relatives of Republican deceased undertook a number of exhumations; however without following any scientific (archaeological) protocols (see Ferrándiz, 2011; Etxeberría et al., 2016 for more information). Since the year 2000 with the exhumation of 13 Republican individuals from the mass grave at the village of Priaranza del Bierzo (León), an increasing number of mass grave exhumations in Spain were brought to the international stage in the context of searching for victims of human rights abuses. This mass grave at Priaranza del Bierzo was the first to be exhumed following archaeological methods and techniques and where the deceased were identified through DNA analysis (Prada et al., 2003; Silva, 2006; Ríos \& Etxeberría, 2016). Between the years 2000 and 2018 there have been more than 600 exhumations in Spain and over 8000 individuals recovered (Aranzadi Society of Sciences). The primary aim of these investigations, after a number of failed attempts to seek justice and therefore legal action, is humanitarian in nature (Martín, Pallín, \& Escudero, 2008; Moreno, 2016).

The Spanish government has created legislation to regulate these exhumations. ${ }^{1}$ Aside from the existing national laws, there are also regional legislation in most of the autonomous communities. For example, in the Basque Country there is an agreement since 2003 between the Human Rights Authority of the Basque Government and the Aranzadi Society of Sciences, which aims to search for those missing in this region during the Spanish Civil War and the dictatorship that followed, and as of November 2017 Valencia approved a law that covers the tasks of search, exhumation, and identification of victims (BOE-A-2017-15371). Within this national trend, the government of the Balearic Islands passed in June 2016 the law regarding the search and recovery of those missing as a result of the Civil War and the Francoist regime with the unanimous support of all parliamentary groups. Since this law was approved in the Balearic Islands there have been a number of searches, exhumations, and identifications of victims of the Francoist regime in various cemeteries on the island of Mallorca totaling 70 individuals exhumed and 14 positive identifications; and in the islands of Ibiza (cemetery of Figueretas) and Formentera (cemetery of Sant Ferran). The latter is the aim of the current paper.

The case study we present here is from the island of Formentera and it provides a good example of how archaeology and anthropology have assisted in the search and identification of human remains from the Spanish Civil War and in the reconstruction of the sequence of events surrounding and following deposition. In addition, this case study aims to illustrate how physical/forensic anthropological knowledge of skeletal trauma can assist in locating individuals in a human rights context, especially when their remains are not located in their primary deposition site.

\section{THE CEMETERY OF SANT FERRAN IN FORMENTERA}

Formentera is the smallest of the Spanish Archipelago of the Balearic Islands located in the Western Mediterranean, with a land surface of $83.2 \mathrm{~km}^{2}$ (see Figure 22.1A). While 


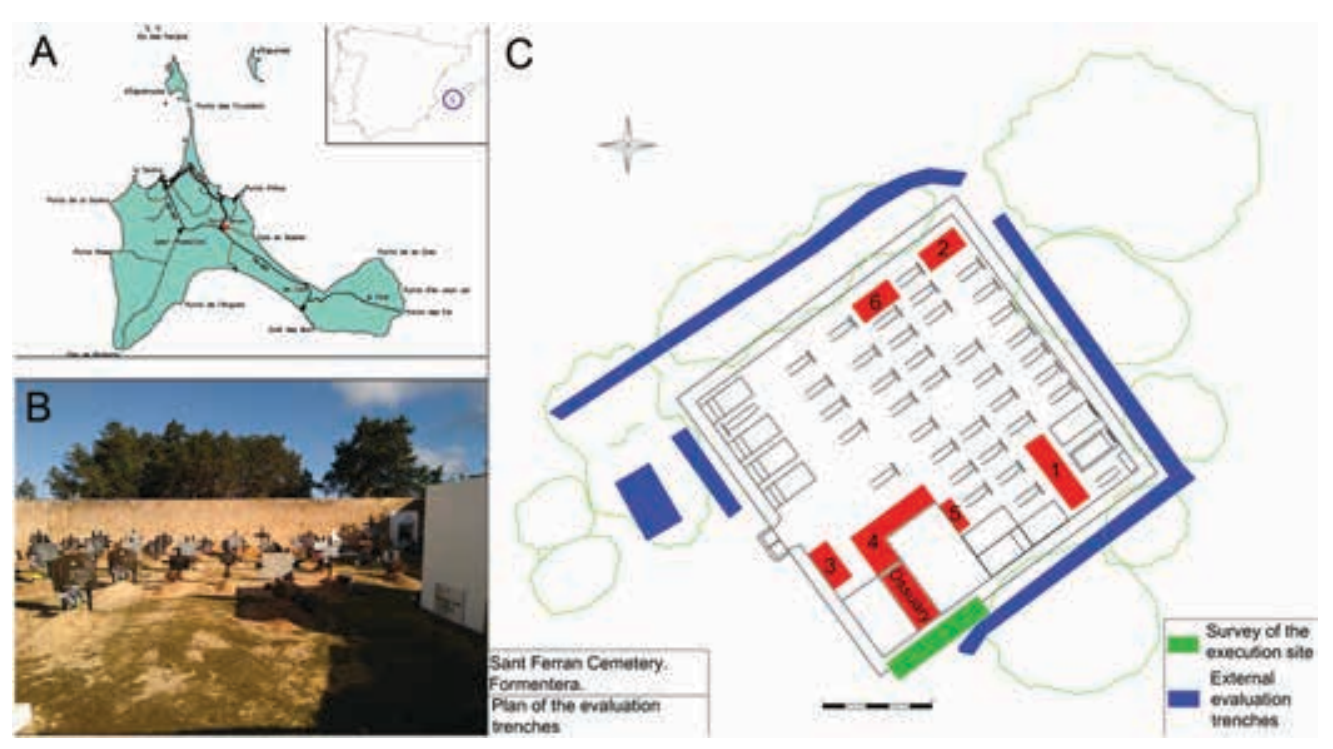

FIGURE 22.1 Overview of cemetary. (A) Map illustrating island of Formentero and cemetery location. (B) Overview of the Sant Ferran Cementery. (C) Map of the cemetery illustrating marked graves, survey areas, external evaluation trenches (blue), and internal evaluation trenshces (red).

today the population is of over 12,000 inhabitants, in 1930 the population was 3,328 inhabitants (www.ine.es).

On July 18th, 1936 there was a military rebellion and all the Balearic Islands except Minorca were taken by the Nationalists. Previously, Formentera had been politically dominated by the Nationalist Confederation of Labor (CNT in its Spanish acronym) and the Salt Syndicate. After several weeks of Republican redomination, the Nationalist forces occupied Ibiza and Formentera. All over Spain, the Nationalists under Franco's leadership occupied the political power. This Fascist political party (Falange Española) was the one to execute the first phase of repression characterized by extrajudicial executions.

In Formentera, the memory of Francoist repression was kept alive by numerous survivors (Parrón, 2015). A total of five (mass) graves have been located through archival research and witness testimony, and this information includes the exact number of victims in each grave and their names, totaling 12 people who faced an extrajudicial execution. In addition to these, there is a communal grave in the new cemetery at Sant Francesc, also in Formentera, which includes the remains of at least 58 individuals who died in captivity at the island's prison of la Savina. The case of Formentera according to a number of authors was a very cruel and bloody repression, which had a great impact on an island with a small population and where families were interrelated (Parrón, 2015).

It is the cemetery of Sant Ferran (see Figure 22.1B) which is the focus of this chapter. The cemetery, which belongs to the church, was founded in 1903 and is still in use today, although since the opening of the new cemetery in 1940, its actual use is minimal. It is today a protected historical site (Bien de Interés Cultural). Here, according to witness accounts, on the March 1st, 1937, five men were buried in a mass grave after being detained by the Fascists and executed outside the cemetery walls. These five executed male individuals included: a 42-year-old sailor; a 37-year-old sailor; a 24-year-old sailor; an 18-year-old (occupation unknown) and another male individual (age and occupation 
unknown). The archaeological and anthropological investigation aimed at locating, recovering, and identifying these individuals.

\section{ARCHAEOLOGICAL AND ANTHROPOLOGICAL INVESTIGATION}

The cemetery of Sant Ferran covers a small area of $250 \mathrm{~m}^{2}$ with graves and, adjacent to the southern wall, a small shed for tools, an ossuary and a columbarium which was built in the 1950s (see Figure 22.1B and C). The excavation team was comprised of seven archaeologists (three of whom are also physical/forensic anthropologists) and carried out their work between the November 29th and theDecember 3rd, 2017, at the request of the association Forum per la Memória d'Eivissa i Formentera, with the consent and support of relatives of the deceased and the financial support of the local council and government (Consell Insular de Formentera and Govern de les Illes Balears).

In the absence of any oficial cemetery register or any plans showing the location of the clandestine graves, it was the oral witness accounts that pointed to two possible locations for the mass grave. These locations were areas of the cemetery with an absence of tombstones. The archaeological strategy targeted these two areas first (see Figure 22.1C). Trial or evaluation trenches were opened and dug by hand (see Figure 22.2A).

The first trench to be dug (Trench 1 ) initially measured $2 \times 1 \mathrm{~m}$ but was later expanded to $3.5 \mathrm{~m}$ in length and a $1 \mathrm{~m}$ depth. During this excavation, three ordinary coffined single graves were found (see Figure 22.2B). These were excluded from being the missing individuals after assessing the decomposition of the coffin, the presence of any artifacts, the position of the remains, and the biological profile according to the anthropological assessment at the site. The anthropological analysis of the human skeletal remains took into account the internationally recognized methods recommended by the Spanish Association of Forensic Anthropology and Odontology (AEAOF) and published in 2013
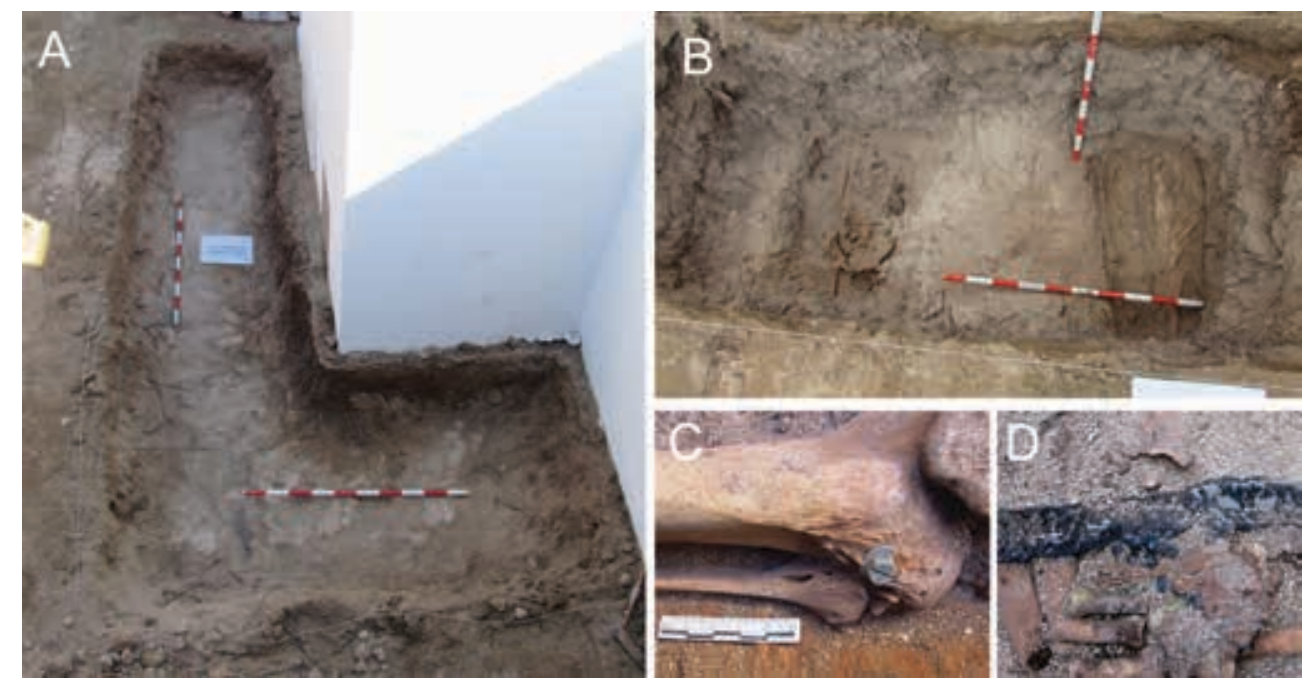

FIGURE 22.2 Initial excavations. (A) Example of evaluation trenches dug to look for burial features. (B) Overview of remains discovered within degraded coffins. (C) Example of remains containing surgical device. (D) Example of remains of a female hlding rosary beads. These remains were able to be excluded as the missing individuals. 
(Serrulla, 2013). One of the individuals was an adult female, with a rosary in her hands (see Figure 22.2D); another was an adult male; and the third coffin had a relatively intact coffin so it was decided not to intefere further. Moreover, the trench section showed a clear cut for these graves within the natural sediment, showing that there was no disturbance or a previous cut for a larger grave of five individuals.

Following the above, a second trench was opened (Trench 2). The location for this one was at the northeast corner of the cemetery and the dimensions of the excavated area were $2 \times 1 \mathrm{~m}$ and $1 \mathrm{~m}$ in depth. A first coffin grave was identified which corresponded to a middle-aged adult male with a denture and evidence of surgery on the left tibia as a result of a fracture (see Figure 22.2C). It would appear that this type of surgery started in the main Spanish hospitals in the 1960s, so that this individual would not have died in the 1930s. Beneath this burial was another adult male individual, also in a coffin lying on the natural and undisturbed sediment. This latter individual was missing its skull and right lower limbs elements, likely due to truncation from the previous burial.

The above trenches, which were initiated from witness testimonies, were thus negative in the search for those killed during the Spanish Civil War. Therefore, four additional trenches were excavated. One was located near the entrance to the cemetery (Trench 3), two others surrounded the columbarium built in the 1950s (Trenches 4 and 5) and the other targeted another area of the cemetery which had no tombstones (Trench 6); but all of these yielded negative results.

As a result of the above, the search expanded to the outside of the cemetery taking into account the knowledge that the executions had taken place outside the southeastern wall of the cemetery. With this in mind, an evaluation trench was opened alongside the perimeter of the cemetery using a mechanical digger to remove the top layer (see Figure 22.3A). The trenches were $70-80 \mathrm{~cm}$ wide and $40-60 \mathrm{~cm}$ in depth and covered an area of $54.30 \mathrm{~m}$. They all proved negative with no undisturbed natural soil. In addition, a metal detector survey was undertaken in the area where the executions had presumably taken place. The latter yielded various $7 \mathrm{~mm}$ caliber projectiles attributed to a Spanish Mauser rifle (Martínez Velasco 2008), a weapon used during the Spanish Civil War. One complete bullet, two fragments, and part of the full metal jacket of a fourth one were found (see Figure 22.3B and C).

Having explored the surrounding and taking into account the investigation within the cemetery walls, it was noted that Trenches 2 and 6 evidenced the reuse of graves. This led to the conclusion that perhaps the space where the five individuals had been buried may have been used for later interments and thus their remains deposited in the ossuary. In order to test this hypothesis, it was decided to assess the thousands of bone elements within the ossuary for any evidence of perimortem trauma which may relate to the events of 1937.

\section{THE OSSUARY}

The ossuary is a small rectangular structure measuring $1.30 \times 3 \mathrm{~m}$ (see Figure 22.4A). There were two different layers or contexts which were clearly distinct. The most superficial layer (strata 04 in Figure 22.4B) comprised mainly fragments of cemetery material such as flower wreaths, plastic, and tombstone debris. Below that was a $55 \mathrm{~cm}$ deep layer which included human remains and sediment (strata 05 in Figure 22.4B). In order to approach this systematically and have some spatial reference, the space was divided into quadrants. Each bone was recovered by hand and assessed for perimortem trauma, 

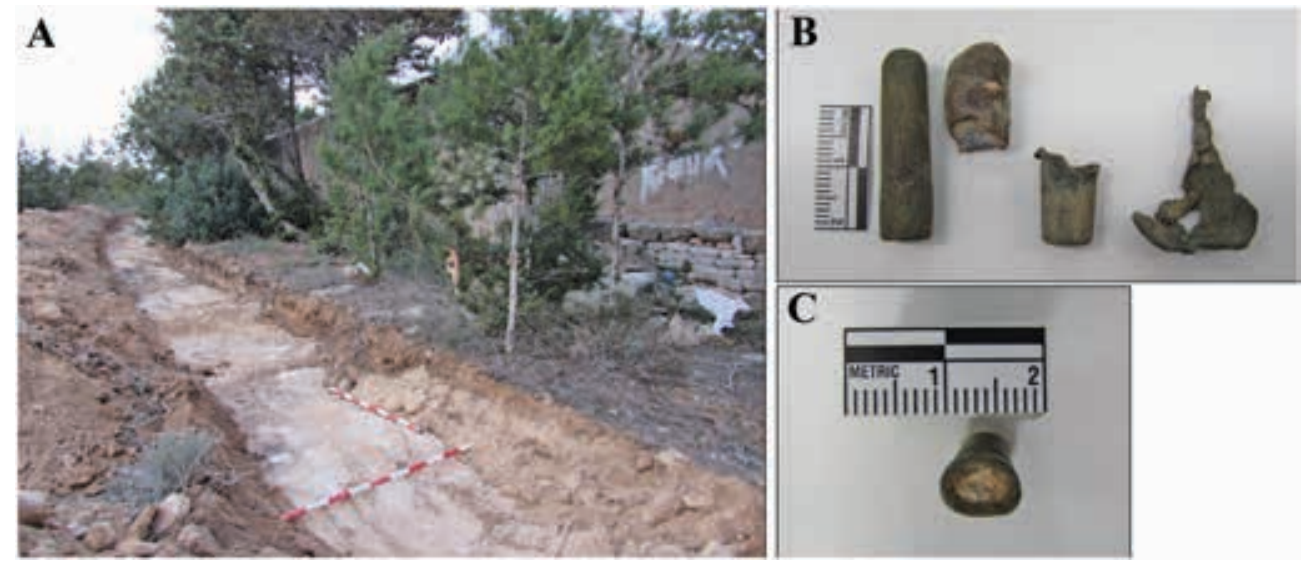

FIGURE 22.3 (A) Example of evaluation trench outside the cemetery. (B) Spanish Mauser rifle projectiles found near the cemetery wall. (C) $7 \mathrm{~mm}$ caliber bullet.

particularly related to gunshot or ballistic trauma, and this process continued until all bones were recovered from the ossuary. All the bones were disarticulated, commingled, and derived from individuals once interred in their primary graves but whose remains were later exhumed and deposited here to create space for new burials. Many of the bones were incomplete, fragmented, and some had significant weathering and other taphomic alterations. Nevertheless, each bone was assessed by anthropologists on site and an attempt was made to identify those with perimortem trauma. Three incomplete bones were found to evidence perimortem trauma. These were located in the northern half of the ossuary and are described below.

The first was an incomplete cranium with occipital, right parietal, and right temporal. This fragment was found in the western corner in quadrant 1 and at a depth of 137 $\mathrm{cm}$. The assesment of the mastoid process and the posterior zygomatic arch were consistent with a male morphology. On the temporal squama there was a perforating circular $7 \mathrm{~mm}$ defect with internal beveling, consistent with an entry wound as a result of high velocity projectile or ballistic trauma (see Figure 22.5A and B).

A second cranial fragment with part of the right parietal and frontal also displayed signs of ballistric trauma. This was found at the intersection of the quadrants at a depth of $122 \mathrm{~cm}$. At the edge of the frontal fragment is the presence of a defect penetrating the outer and inner cranial vault which is semicircular. This defect has a diameter of $7 \mathrm{~mm}$ and internal beveling. Once again, these traits are characteristic of a entry wound resulting from high velocity projectile or ballistic trauma (see Figure 22.5C and D). Externally there is a clear radiating wet bone or perimortem fracture likely associated to this entry wound.

The third element displaying ballistric trauma was a proximal third of an adult left humerus. This incomplete bone was found in the eastern corner of quadrant 1 . The vertical and transverse diameters of the head $(40.6 \mathrm{~mm}$ and $42.1 \mathrm{~mm}$, respectively) are consistent with male dimensions following Spanish discriminant functions for sex estimation (Alemán et al., 1997). In the diaphysis there was a small bevel from which there are radiating fractures. These radiating fractures appear as a double buttefly shape steming from an initial point of contact as a result of gunshot or ballistic trauma (see Figure 22.5E). 

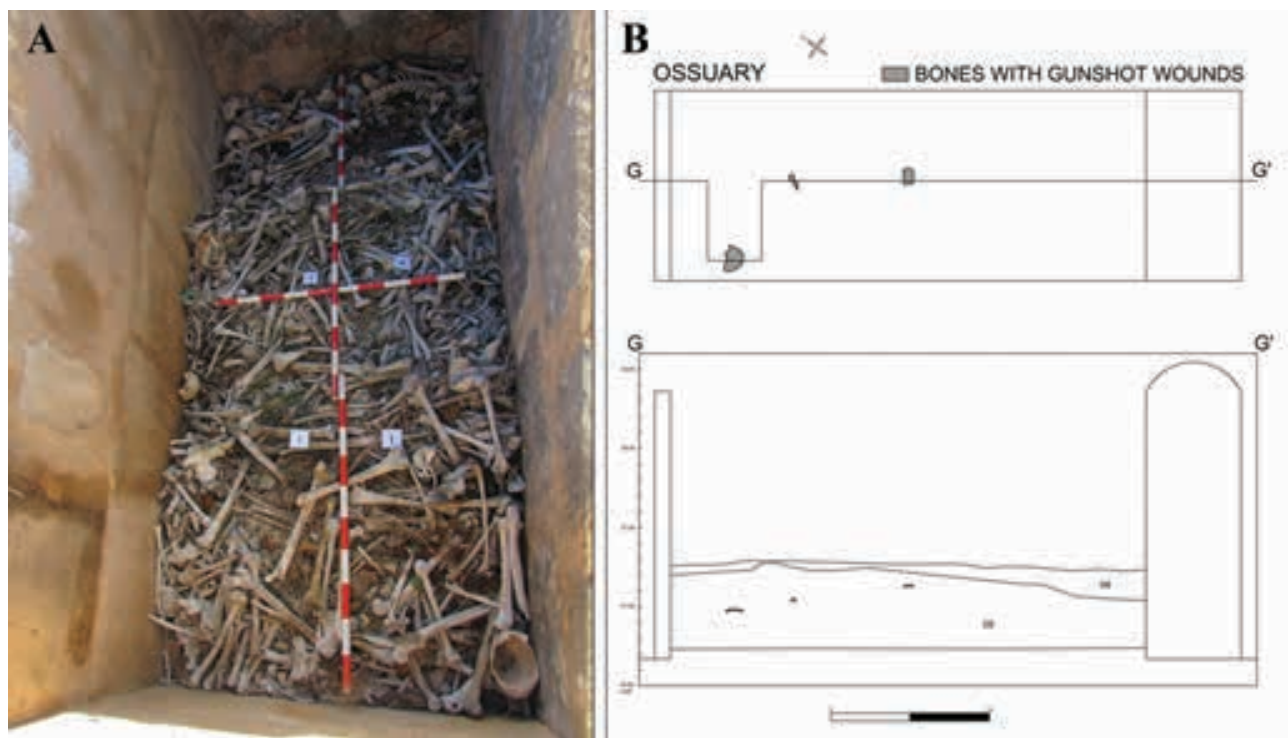

FIGURE 22.4 The ossuary. (A) Aerial view of the ossuary, with strata 05 exposed and the division into quadrants for a more systematic documentation. (B) Profile maps from the ossuary, illustrating location of bones with gunshot wounds.

The characteristic of these lesions, regarding both their typology and location are similar to those extensively documented for executed victims during the Spanish Civil War (Ríos et al., 2014; Congram et al., 2014). In summary, the investigation of the ossuary and the anthropological assessment of the human remains on site, identified three bones with perimortem trauma compatible with high velocity projectile or ballistic trauma. These bones belong to at least two adult individuals, at least one of whom appeared to be male. The diameter of those defects, especially the cranial ones, would also be compatible with the projectiles found by the outer wall of the cemetery. With this in mind, it could be hypothesized that those bones belonged to at least two of the individuals being searched who were executed and buried during the Spanish Civil War.

\section{IDENTIFYING OF THE DECEASED AND RECONSTRUCTION OF THE EVENTS}

To test the hypothesis that the bones with perimortem trauma were the remains of at least two individuals from the group of five men executed in 1937, two lines of enquiry were followed. The Civil Registers were checked to explore whether or not any of the people buried in the cemetery had died as a result of gunshot trauma. In addition, the bones were submitted for DNA analysis alongside DNA reference samples from living relatives.

The Civil Register in Formentera includes every death (excliuding those executed during the Spanish Civil War) with the name of individual, date, burial place, and cause of death. ${ }^{2}$ Archival research of this Register from 1903 onwards when the cemetery of San Ferran had its first burial did not find any cause of death associated with gunshot wounds or ballistic trauma. The only case that was to be considered further was a male who died due to a 'brain injury' (traumatismo cerebral according to the Register) but 

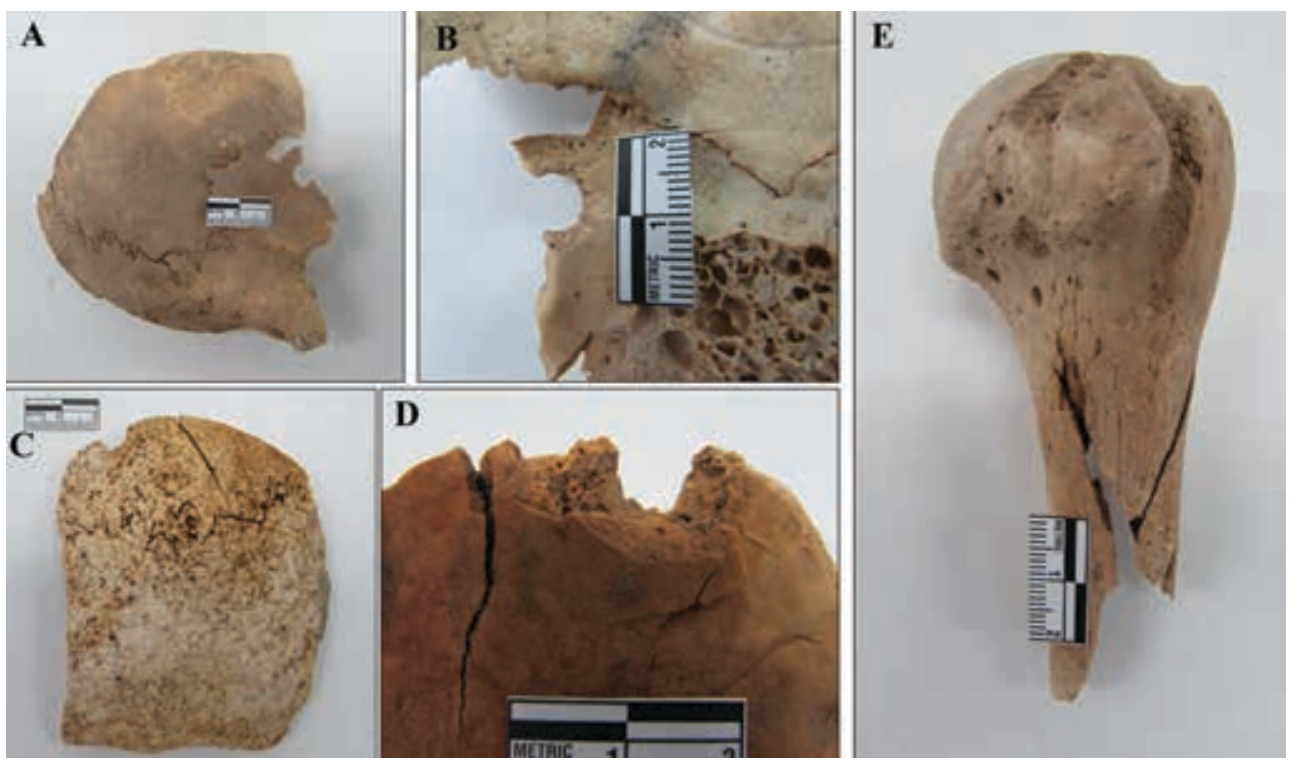

FIGURE 22.5 Ossuary bones displaying perimortem trauma. (A) An incomplete cranium with a circular $7 \mathrm{~mm}$ defect on the temporal squama consistent with an entry wound as a result of high velocity projectile or ballistic trauma. (B) Internal beveling in the same bone. (C) Cranial fragment with a semicircular defect in the frontal consistent with an entry wound as a result of high velocity projectile or ballistic trauma. (D) Internal beveling on the frontal bone. (E) An adult left proximal humeral shaft with a small bevel from which there are radiating fractures, consistent with ballistic trauma.

further research found that this was caused by a fall from a cliff. With regard to the DNA samples, selected relatives from the five victims submited reference samples; however, the bone fragments did not yield sufficient mtDNA (there was no nuclear DNA) and therefore the genetic testing was unsuccessful.

How then to test the hypothesis that the three bone fragments correspond to at least two of the five individuals? Firstly, the information obtained through oral testimony clearly indicated that the five men were detained, executed outside the cemetery, and buried in the cemetery of Sant Ferran in Formentera. Secondly, the cemetery ground was investigated as well as the outside perimeter with archaeological methods and the absence of a mass grave and the presence of individuals with perimortem trauma compatible with high velocity projectiles were found in the ossuary. Moreover, these fragments with trauma belonged to at least two individuals, at least one of them male, with defects compatible with bullets from a Mauser rifle such as those found with the metal detector outside the cemetery wall. We believe that if this information is takem into account along with the fact that no person was buried in the cemetery who had died from a gunshot wound, this provides strong evidence that those bones belong to the Spanish Civil War victims that the team was searching for; however, there appears to be no means to obtain a postive identification. 


\section{LESSONS LEARNED}

Since 2000, the number of Spanish Civil War exhumations by professional archaeologists, anthropologists, forensic pathologists, and other specialists have increased in order to provide a dignified burial and closure for relatives. This case of Sant Ferran is one of such interventions to search, attempt to locate, recover, and identify those who were executed and buried in clandestine graves during the Spanish Civil War and the dictatorship that followed. The case presented here to locate and identify five men who died in 1937, provides scientists with a number of lessons that may help in future investigations.

- It cannot be stressed enough the importance of having a profesional team of historians to undertake the archival research, a number of archaeologists to systematically search the cemetery and eliminate areas with confidence, the use of different methods such as metal detector to identify projectiles, and in particular a strong team of anthropologists to eliminate areas where individuals have been found buried there. In particular for this case, it was the anthropological assessment of human remains with perimortem trauma that yielded results.

- Although faced with numerous limitations, including the volume of commingled bones and bone fragments in the ossuary, the alteration of bones due to various taphonomic factors, and the lack of DNA results, by reconstructing the remains and eliminating others; some answers were provided. Areas believed by witnesses to contain the remains were excluded and a potential scenario for the disposition of the remains was constructed. Although definitive answers and positive identifications could not be obtained, the relatives of the deceased have more information and potential evidence that the individuals were there and subsequently were placed in the ossuary, and these answers may provide at least a little closure to the families.

- There are limits to forensic science, and much of it depends on the preservation of context and associated evidence. Note all cases can be solved with $100 \%$ confidence.

\section{DISCUSSION QUESTIONS}

Do you believe that the authors have enough information to determine whether the remains belong to the missing individuals from the Civil War? How confident are you and how would you present the results in a case report?

Are there any additional methods that the team could carry out to further prove that the remains belong to those individuals?

22.3

The remains with perimortem gunshot trauma represent a minimum of two (and a maximum of three) individuals. Where then are the remains of the individuals who were executed that same day? Are there any other methods you would employ to search for additional remains? 


\section{ACKNOWLEDGMENTS}

We would like to express our gratitude to Dr Escribano (Madrid) and Dr Galtés (Barcelona), for providing information on the type of surgery and its chronology associated with the surgical device discovered during excavations.

\section{NOTES}

1. BOE 2007: Ley 52/2007 of December 26th, regarding a number of measures to recognise those who died violently during the Civil War and the dicatorship that followed; BOE 2011: protocol for the exhumation of victims from the Spanish Civil War and the dictatorship; BOGC2017: reform of the previous law 55/2007 of 26th December 2007.

2. From 1994 onwards there is no specific information on the cause of death (BOE 13489 ORDEN of June 6th, 1994) but the Institute of Legal Medicine who has Formentera under its jurisdiction have indicated that there have been no deaths as a result of gunshot wounds or ballistic trauma (Juan Ramón Sancho-Jaráiz, personal comment).

\section{REFERENCES}

Alemán, I., Botella, M., \& Ruiz, L. (1997). Determinación del sexo en el esqueleto postcranial. Estudio de una población mediterránea actual. Archivo Español de Morfología, 2, 69-79.

Aranzadi Society of Sciences. (n.d.). Retrieved October 1, 2018, from http://www.aranzadi.eus/?lang=en

Congram, D., Passalacqua, N., \& Ríos, L. (2014). Intersite analysis of victims of extraand judicial execution in Civil War Spain: Location and direction of perimortem gunshot trauma. Annals of Anthropological Practice, 38(1), 81-88.

Etxeberría, F., García-Rubio, A., Herrasti, L., Jiménez, J., \& Márquez-Grant, N. (2016). Mass graves from the Spanish Civil War: Exhumations, current status and protocols. Archaeological Review from Cambridge, 31(1), 83-103.

Ferrándiz, F. (2011). Guerras sin fin: guía para descifrar el Valle de los Caídos en la España contemporánea. Política y Sociedad, 48(3), 481-500.

Juliá, S. (1999). Víctimas de la Guerra Civil. Madrid, Spain: Temas de Hoy.

Martín Pallín, J. A., \& Escudero, R. (2008). Derecho y Memoria Histórica. Madrid, Spain: Trotta.

Martínez Velasco, A. (2008). Breve introducción a la cartuchería para arqueólogos. Sautuola, XIV, 383-398.

Moreno Gómez, F. (2016). Los Desaparecidos de Franco. Un Estudio Factual y Teórico en el Contexto de los Crímenes Internacionales y las Comisiones de la Verdad. Madrid, Spain: Alpuerto.

Parrón i Guasch, A. (2015). La represión franquista en Ibiza y Formentera. Memòria antifranquista del Baix Llobregat. 34-38. 
Prada, E., Etxeberría, F., Herrasti, L., Vidal, J., Macias, S. \& Pastor, F. (2003). Antropología del pasado reciente: una fosa común de la Guerra Civil Española en Priaranza del Bierzo (León). In M. P. Aluja, A. Malgosa, \& R. M. Nogues (Eds.), Antropología y Biodiversidad Volumen I (431-446). Barcelona, Spain: Ediciones Bellaterra.

Preston, P. (2012). El Holocausto Español. Debate. Barcelona.

Ríos, L., \& Etxeberría, F. (2016). The Spanish Civil War forensic labyrinth. In O. Ferrán \& L. Hilbink (Eds.), Legacies of violence in contemporary Spain: Exhuming the past, understanding the present (pp. 174-198). New York: Routledge Studies in Modern European History.

Ríos, L., García-Rubio, A., Martínez, B., Herrasti, L., \& Etxeberria, F. (2014). Patterns of perimortem trauma in skeletons recovered from mass graves from the Spanish Civil War (1936-1939). In C. Knüsel \& M. J. Smith (Eds.), The Routledge handbook of the bioarchaeology of human conflict (pp. 621-640). London, UK: Routledge.

Serrulla, F. (Ed.). (2013). Recomendaciones en Antropología Forense. Asociación Española de Antropología y Odontología Forense.

Silva, E. (2006). Las fosas de Franco. Madrid, Spain: Temas de Hoy. 
